\title{
The public brand between new practices and public values
}

Corinne Rochette, University of Auvergne, France

$1^{\text {st }}$ draft of the article published in International Review of Administrative Sciences, 2015 81(2), 326345.

Pole tertiaire site Rotonde, 26 avenue Léon Blum, Clermont Ferrand 63000 France

Email: corinne.rochette@udamail.fr

Executive summary ${ }^{1}$ : The public brand is a relative newcomer to the public sphere. It is an expression of public marketing and an outcome of NPM. It is a lever that allows public organisations to get across their identity, assert their legitimacy and provide markers for the evaluation of their actions. Little research has been conducted into what it actually covers. The analytical framework of the social representation and, more specifically, that of the central core theory, makes it possible to identify, on the basis of a sample of twenty public brands, the values it carries, the influence of context on the configuration of the values and, more broadly, the use made of the public brand.

Points for practitioners: In a context of growing competition, a legitimacy crisis, fiscal pressures, technological revolutions that change relations with the user-client and staff, the place and operation of public organisations are being turned upside down. The brand is an important but underexploited lever to restore legibility and legitimacy to public organisations, but also to assert its difference, express its skills and mobilise its officials. It is a way of combining traditional values and new practices dictated by performance requirements. Too many public brands are registered without coming into any real use. The establishment of the brand first calls for thought to be given to its anchoring, by defining pillar values that allow practices (that are sometimes misunderstood or poorly accepted) to be converged with the historical values associated with public services. Values are the basis of the discourse, they build the representation and are the key to the identity of public organisations. Furthermore, the field of public action is characterised by several branding levels that need to be considered according to the potential for legitimation presented by each.

\footnotetext{
${ }^{1}$ The author would like to express her sincere gratitude and acknowledgement to the proofreaders for the comments and suggestions that have made it possible to improve this study.
} 
Keywords: New public management, public brand, public values

Corinne Rochette is a Lecturer in Management at the University of Auvergne. She teaches strategy, relationship marketing, public and territorial marketing. A teaching researcher at the LARGEPA, University of Paris II and at the CRCGM University of Clermont, she has authored or co-authored several publications on relationship management, market orientation, public marketing and territorial strategies. She is currently conducting research into the creation and the use made of public brands.

\section{Introduction}

The rollout of a marketing approach within public organisations (POs) $)^{2}$ stems from the NPM movement, which advocates the implementation of the management principles and techniques used in the private sector within POs to improve their performance and develop a market orientation (Hood, 1991; Pollitt, 2007). It mobilises new tools and practices that give rise to a great deal of criticism and tensions (Mazouz et al. 2012). Unlike NPM, it takes place in small steps because of the impossibility of transposing a comprehensive marketing approach to POs. Market orientation (MO) in its customer dimension is usually considered as the main marker of adopting a marketing approach, but for some (Muller, 2006, Denhardt and Denhardt, 2000; Brewer, 2007), it proves incapable of offering a satisfactory integrating explanatory framework to understand the peculiarity of PO marketing practices because of the emphasis on the economic value that weakens the central values (legitimacy, trust, justice, equality, continuity) (Hood, 1995), the insufficient consideration given to the political dimension, the excessive attention paid to the customer (Brewer, 2007) and the lack of recognition of objectives other than profit (Gromark and Melin, 2013). In the absence of an overall analytical framework, the place and the issues associated with marketing are discussed in terms of the practices of public organisations, however, only few marketing practices have been studied outside user satisfaction.

\footnotetext{
${ }^{2}$ The debate about the place of marketing in the public sector is far from recent and Graham (1994) reports a conference of researchers and practitioners in 1919 organised by Yale University on the theme "exploring and developing governmental marketing" highlighting the difficulty of using marketing in the public sphere.
} 
Urde (1994) and Melin (1997) propose to consider the brand to study how marketing transforms the organisation.

Few studies explore the public brand development process, despite the fact that the public sector is an important part of the activity, that the names and logos are known to the general public and that the question of identity is crucial for these organisations (Brunsson and Sahlim-Andersson, 2000). While, for some, brand development in the public sector is the logical continuation of NPM and the concurrent adoption of the market orientation, for others (Gromark and Melin, 2013) it deserves to be studied on the basis of the new framework provided by the brand orientation developed by Swedish researchers (Urde 1994; Melin, 1997). This makes it possible to overcome the criticisms levelled against market orientation and to understand the marketing practice of $\mathrm{PO}$ as a whole, starting with the public brand.

The brand is a matter of survival for POs operating in a difficult environment: shrinking operating budgets, pooling of administrations (mergers of the ANPE and ASSEDIC in France, of universities, regional groupings) and the crisis of citizen confidence. POs seek to assert their place by expressing commitment and legitimacy through a strong brand (Dahlqvist and Melin, 2010). The public brand must create the trust necessary for the smooth operation of the institutions (Delgado-Ballester and Munuera-Aleman, 2005) and contribute to their transparency and visibility. It expresses a strategic intent (Urde, 1997) and an organisational intent (Urde 1994). It is a strategic resource (Melin, 1997), a management tool for the organisation (Urde 1999) built on core values (Urde, 2003). But what is the brand in question? It covers a variety of situations that this research aims to identify and resituate in the form of a typological outline. It uses potentially conflicting values (public service mission and performance goal derived from NPM). How do these values exist side by side? The theory of the central core, using values as input, provides a simple but tried-andtested theoretical framework to decode the representation given by the PO of the public brand on the basis of the mix of values and the attention given to legitimising the action. Based on this theoretical framework and the outline of a typology of public brands, after having presented the methodological framework, twenty brands will be analysed and the results discussed before presenting our conclusions. 


\section{THE PUBLIC BRAND}

The development and use of public brands is part of a broader strategy to develop the intangible heritage of the State. For Levy and Jouyet (2006), the State is a bad manager of its intangible rights, including its brands. It is in this context that the Agence du Patrimoine Immatériel de l'Etat ${ }^{3}$ (the Agency for the Intangible Heritage of the State) was created.

\subsection{The public brand for a development and legitimisation of public action}

When addressing the issue of public brands, the first obstacle encountered is how to define it. A review of the literature reveals the lack of definition of public brand, probably because of the recency of the concept and low quantity of research conducted on this subject that has not yet made it possible to stabilise the conceptual elements. It is succinctly defined in its sectoral application (hospital brand, museum brand, university brand). For the APIE, the public brand basically appears in the form of a corporate brand. It has similarities with the private brand (corporate and product) in terms of the factors conventionally applied to define the brand (graphics, legal protection, practical and utilitarian dimensions of identification, recognition, warranty), but differs on a number of points, such as the dominant issue, its nature, the priority desired effects, the targets and the orientation given to it (table 1).

Table 1: Distinctive features of the private brand/public brand

\begin{tabular}{|l|l|l|}
\hline & Private brand & Public brand \\
\hline Dominant issue & Economic & Political \\
\hline $\begin{array}{l}\text { Foundation of } \\
\text { marketable values }\end{array}$ & $\begin{array}{c}\text { 1. Economic (efficiency, } \\
\text { quality, price promise...) }\end{array}$ & $\begin{array}{l}\text { 1. Civic, } \\
\text { 2. Economic (good use of public } \\
\text { money or financial } \\
\text { valorisation) }\end{array}$ \\
\hline Dominant concern & $\begin{array}{l}\text { The brand image (evaluation, } \\
\text { orientation) }\end{array}$ & $\begin{array}{l}\text { The identity (identification, } \\
\text { construction, dissemination) }\end{array}$ \\
\hline The brand expresses & $\begin{array}{l}\text {-A promise } \\
\text { (evaluated by the client) }\end{array}$ & $\begin{array}{l}\text {-An intention (Urde, 1997), a } \\
\text { commitment } \\
\text { (evaluation by several stakeholders, } \\
\text { including elected representatives, } \\
\text { senior civil servants) }\end{array}$ \\
\hline
\end{tabular}

\footnotetext{
${ }^{3}$ The APIE was created in 2007 within the Ministry of the Economy, Finance and Industry and the Ministry of Budget, Public Accounts and State Reform. Its missions include supporting public organisations with the definition of brand protection and development strategies.
} 


\begin{tabular}{|l|l|l|}
\hline $\begin{array}{l}\text { Priority effects } \\
\text { sought }\end{array}$ & $\begin{array}{l}\text {-Create economic value } \\
\text {-Gain customer loyalty } \\
\text {-Stand out from the competition }\end{array}$ & $\begin{array}{l}\text {-Bring public action to the citizen's } \\
\text { awareness, legitimise } \\
\text {-Guard against appropriation } \\
\text { attempts (being a warranty) } \\
\text { - Change practices, the image of the } \\
\text { PO }\end{array}$ \\
\hline $\begin{array}{l}\text { Priority targets of } \\
\text { the brand }\end{array}$ & -External & -Internal and external \\
\hline $\begin{array}{c}\text { Orientations } \\
-\quad \text { main } \\
-\quad \text { secondary }\end{array}$ & $\begin{array}{l}\text {-Transactional/economic } \\
\text {-Relational }\end{array}$ & $\begin{array}{l}\text {-Informational/relational } \\
\text {-Economic }\end{array}$ \\
\hline Nature of the tool & $\begin{array}{l}\text {-Commercial (a component of the } \\
\text { offer) }\end{array}$ & $\begin{array}{l}\text {-Managerial (a steering tool, to ensure } \\
\text { coherence of actions) }\end{array}$ \\
\hline
\end{tabular}

Source: author's own

It cannot be confused with a simple name (that of the PO) or be nothing more than an institutional communication devised for the short-term, as it implies setting something in motion and is based on a long-term logic. By embracing a brand approach, POs are forced to question their identity, their specific values and the particular project (intention) that it expresses (Vernette 2008) as well as the image they want to convey, elements that are particularly significant due to the significant transformations undergone by the PO (operating principles, values triggered by NPM). The public brand can be defined as "an instrument with a managerial and communication dimension intended to give visibility to the organisation, to carry its values, to support the transformation of the organisation's link to the user and to facilitate internal mobilisation and external rallying". It expresses an intention, it helps to enhance its features, its know-how and its skills and to shore up user satisfaction by paving the way for "accountability" that "could be based on the ability to give a full account at any time on respect for a set of values" (Joannidès and Jaumier, 2013).

\subsection{The public brand as an uncoordinated set}

An overview of the public brands registered with the $\mathrm{INPI}^{4}$, reveals a significant heterogeneity and plurality of the brands. They are associated with the territorial authorities, public institutions or the State (ministries in most cases). They can be the marker of an institution (the Marine Nationale, INSERM, CHU), of an object (Parc natural regional des Ardennes, Vulcania), a service offered (AMELI, Bison Futé), a programme or a campaign (Nutrition santé, Vigipirate), an event (Annecy 2013), a

\footnotetext{
${ }^{4}$ Institut National de la Propriété Industrielle (French Patent Office)
} 
management and/or project territory (Le Grand Paris). Can this set be interpreted on the basis of the principles of portfolio management of brands or brand architecture (Kapferer, 1999) developed for business? It appears that they are proving difficult to transpose. The recency of the phenomenon shows an embryonic brand management process, more spontaneous than constructed, where the use made of the copyrighted material is very random.

A review of a hundred public brands registered in the INPI database allows us nevertheless to distinguish broad categories of markers (figure 1) by combining the analysis levels of public governance (Facal and Mazouz, 2013) and the principle of brand architecture ${ }^{5}$ (Aaker and Joachimsthaler, 2000; Kapferer, 1991).

Figure 1: A typology of public brands

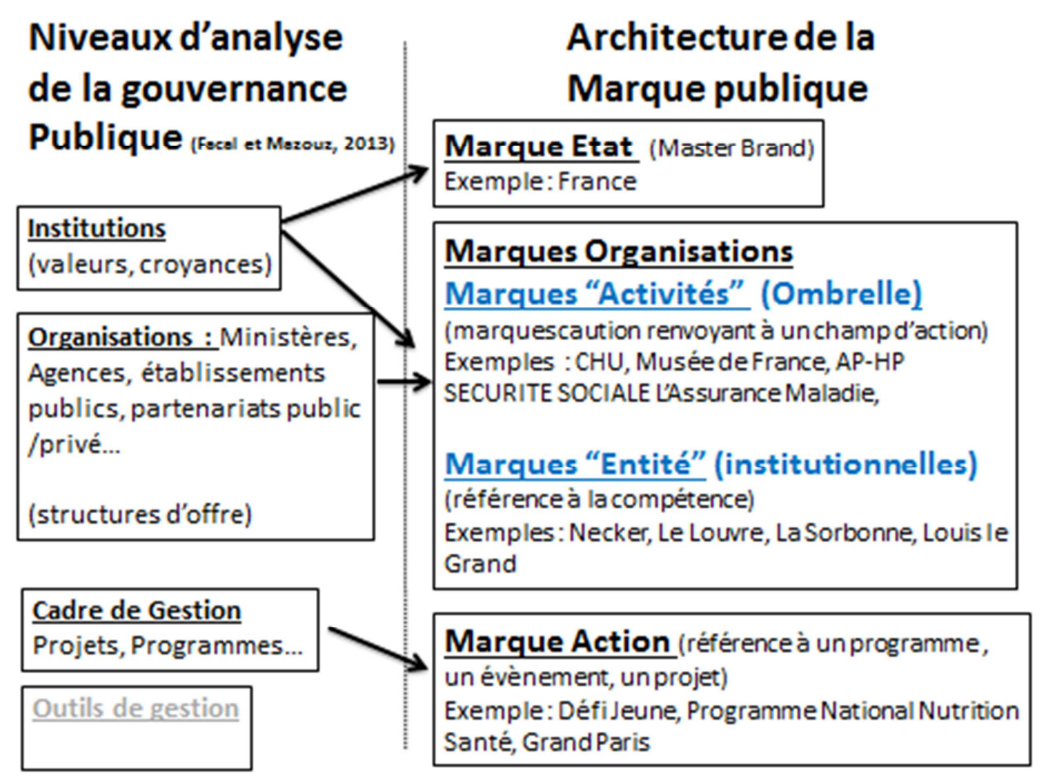

Source: Author's own

Public brands are grouped into four broad categories. The first category refers to the superior entity, i.e. the State. It is the transversal master brand, guardian of the major principles and values carried by society. It differs from the "France brand" that is currently being created, a collective brand (shared by public and private

\footnotetext{
${ }^{5}$ Brand architecture is defined as an organised structure of the brand portfolio clarifying the role of the brands and the nature of relationships between these brands (warranty, ...). Translated from Aaker and Joachimsthaler (2000).
} 
organisations), more akin to the label, designed to strengthen the region's attractiveness with an essentially economic aim. The "State brand" secures coherence and covers all the other public brands. It is the responsibility of public officials. The second category, "organisation brands" are based around "activity" brands and "entity" brands and it is on this level that the development of public brands is focused. They are the result of supply structures that allocate resources and shoulder the results of the public action (Facal and Mazouz, 2013). The first refer to the major fields of public intervention, they are known to users and associated with a certain type of standardised services, they are, at first sight, close to the commercial umbrella brands. The second express a specificity, a competence, a particular expertise, and are in a way "institutions" in that they have a high value and are seen as references, irreplaceable and unique. The third category, that of the "action" brands, relates more to communication elements designed to promote and explain the content of a programme, a project or an event. These different categories coexist but to a more or less marked proportion, without the idea of hierarchy or domination. The absence of hierarchical concept could be a specificity of public brands.

While the public brand refers to the field of action of the public actor, the development of public-private partnerships as a public management modernisation tool (Guzman and Sierra, 2012) blurs the association between brand and organisation. At first sight, as far as the brand is concerned, PPPs technically fall under one of the forms of brand alliance (shared development, co-branding, joint communication) set out by Michel and Cegarra (2001). Indeed, even if the structure created (joint venture, consortium, etc.) to carry the partnership can be the owner of the brand, the private and public partners can showcase their contribution and associate their name with the subject of the partnership to strengthen their image (Kirovska and Simonovska, 2013). But in actual fact, in the event of difficulties, the image is asymmetric. The failure primarily affects the image of the public structure, as was the case of the MMArena in Le Mans. This produces a decoupling of the effects of the brand between the positive effects associated with the private and public structures and the negative effects mainly imputed to the public structure, as if accountability was greater for PO, which are obliged to account for their good management of public funds, underlining the difficulty of developing strong and coherent common values (Urde, 2003). 


\subsection{Public brands to reconcile public values and NPM}

The literature highlights the difficulty of making specifically public institutional values (Schedler and Proeller 2007) exist side by side with market values (Kernaghan, 2000; 2003) and democratic values (Denhardt and Campbell, 2006; Pierre, 2009). This issue is not just relevant to PPPs. Indeed, the introduction of market mechanisms within the public service leads to changes in the internal operation (Suleiman, 2003) and raises the question of alignment of public values with the requirements of effectiveness and efficiency arising from NPM (Rondeau, 2007), while leading to new models (Denhardt and Denhardt, 2000; Pollitt and Bouckaert, 2004, Olsen, 2008), to new conceptions of public administration and new practices. Studies have explored the processes and issues related to the alignment of logics of identity and logics of action to better understand how the changes take place (Fortier, 2013), prompted, for example, by public service motivation (Perry and Wise, 1990) and their developments, but also logics of power. The tension created in public organisations comes from the friction between new operating methods introduced in the public sphere and spawned by the managerial logic with traditional public values (Fortier, 2010a).

As a social representation, the public brand works as a system that interprets reality. In its functional vision, it gives meaning to behaviour and makes it possible to grasp the reality. It conveys the behaviour and practices of public organisations. It can be seen as a social representation taking on four functions (Abric, 1994):

- a function of knowledge: understanding and explaining reality, learning about an object (here, knowledge about a public organisation)

- an identity function: defining the identity and safeguarding the specificity,

- a support function: justifying a posteriori the stances and behaviours

- an orientation function: guiding the behaviours and practices.

The theory of the central core as a structural approach to social representation provides a useful tool for addressing the organisation of the values held by a brand. This theory is based on the fact that social representation is the manifestation of social thought, of a number of collectively and historically determined beliefs whose questioning alters the identity and continuity of the object (Abric, 2001). Thus the representation is hinged around a central core directly related to the values and standards, and peripheral elements whose function is to ensure tangibility. The 
central core gives meaning to the elements, organises them and stabilises their representation. It brings meaning (organising function) but it is also the element via which the other elements are transformed (generator function). It develops slowly and is disconnected from reality. The peripheral system, for its part, fulfils a tangibility function by making reality understandable and communicable. It allows transformations to take place by integrating new information or changes in the environment, by giving them a minor or exceptional status but also by reinterpreting them in the direction of the central meaning (control function). The peripheral system performs a defence function when the central core is threatened by inconsistencies between the practices of the brand and the core elements. This theory, though strong, has been little used by management research. Some researchers use it in marketing in studies on branding, brand identity, change of name (Michel, 1999; Cegarra and Michel, 2001; Vernette, 2008), political co-branding (Albouy et al, 2014; Cegarra and Michel, 2001) or brand extension (Michel, 1999). It has certain similarities with the notions of "brand heart" and "brand core" but, unlike the latter, it makes it possible to better address the phenomena in their dynamics and identify the elements behind their evolution.

The brand is built on an axiological base (Urde, 2003) and therefore it is necessary to identify the values it expresses. Most researchers (Sayre, 1958, Perry and Rainey, 1988 Rainey, 1989) who have explored the values consistently find a difference between private values and public values. While the identification of private values seems easy, the identification of public values is more delicate (Bozeman, 2007).

The conceptualisation of the values is usually done at the level of individuals and private values, yet, while public values can be individual, they are also those of a society. Public values are usually intrinsic, shared, and point to what the public sector should be. Many researchers agree on the difficulty of conceptualising and instrumentalising them. A distinction is made between individual public values and those of society. The first refer to a preference of individuals regarding the rights and benefits to which citizens are entitled and the obligations to which their representatives are subject. The values of a society result from a normative consensus about the rights, benefits and privileges to which citizens should be entitled or not; their obligations towards society, the State and others as well as the principles on which the action and policies should be based. While individual public values can be identified from surveys, some advocate intuition to pinpoint those of 
society (Ramsey and Depaul, 1999), to postulate them (Antonsen and Jorgensen, 1997) or to use case studies to identify how the value is managed through the public service (Frederickson and Hart, 1985; Frederickson 1994, 2002).

The hybridisation of public and private cultures is the result of a mixture between values from the civic world and others from the commercial world (Buffat, 2014). Rondeaux (2007), Emery and Martin (2010) stress the hesitation of current values between values borrowed from private organisations (profitability, productivity, focus on performance indicators, etc.) and the values that make up the particularity of the public sector (mission of general interest, equal treatment, legality, integrity, etc.). The public brand as a mode of expression of an identity, reflects the configuration of these values. It can be seen as an element that goes into the construction or redefinition of the identity of a $\mathrm{PO}$, which is underpinned by the values. It expresses an organisational identity through affirmations and comments (Ashforth and Mael, 1989, 1996). While, for some researchers, organisational identity exists outside of the members of the organisation, for others it is constructed by them (Ravasi and Schultz, 2006). An external positioning makes it possible to study how the organisation sees its identity with regard to its environment and thus grasp the image it intends to project and the values it wishes to highlight.

Over the past decade, several countries (Canada, Denmark, and Spain) have undertaken approaches to identify the traditional values and the new ones associated with the civil service. The results support the findings of the Silicani White Paper (2007) on the future of the civil service in France, those of the survey published in 2012 by the network of French Civil Service Schools and confirm the results of research into public service motivation (Hondeghem and Vendenabeele 2005; Fortier, 2010b).

Based on these studies, two major categories of values that garner consensus can be identified:

- traditional reference values, republican in nature coming from the civic sphere: freedom, equality, fraternity and secularism, general interest, continuity, neutrality, equal treatment, solidarity, loyalty, respect for diversity, integrity, selflessness, legality, exemplarity, integrity,

- more "managerial" values borrowed from business, resulting from the changing context and the dissemination of NPM principles, values traditionally 
associated with the commercial sphere: effectiveness, efficiency, safety, quality, performance, evaluation, autonomy.

\section{The methodological framework}

Studying the public brand can help to understand to what extent the experiences of reforms and the changing practices inspired by NPM translate into PO concepts. The content of the brand makes it possible to access the representation that the PO wants to give of itself. The brand is a way of expressing this identity and of activating values because knowledge remains patchy on the activation of the values (Rondeaux, 2007). The introduction of new concepts and practices within the PO serves to disrupt and trigger a change in the core values. Social representation (Abric, 1994) and the theory of the central core (Abric, 1979) offer an interesting interpretative framework to understand the trade-offs and changes in values and their configuration. Does the public brand combine classical values with the demands of efficiency/effectiveness derived from NPM (Brereton and Temple, 1999) or does it set out to mainly assert the historical values, illustrating maybe a phenomenon of withdrawal or resistance? Based on the principle that the brand is narration (Lewi and Lacoeuilhe 2007; Kapferer, 1991) and on Foucault's idea that discourse is behind the construction of identities, the methodological approach adopted is to access the representation of the public brand by identifying the associations of which it is the object (Abric, 2001; Moliner, 2001). We therefore seek to identify the values associated with it, since they are the ones that structure the "discourse", to resituate them (functions of social representation) and to identify if they are synonymous with changes (peripheral elements) or stability (central core). In order to assess how the public brand stages public values we selected twenty "organisation" type brands (table 2) according to the previously proposed typology (figure 1). This choice is the result of a search for public organisations associated with the term "public brand," the identification of examples of public brands presented by the agency of the intangible heritage of the state and observation of a hundred brands registered with the INPI. We deliberately excluded from our analysis the brands relating to PPP which, due to their specificity, do not constitute a public brand in itself, and local authorities whose brands represent a dimension of territorial marketing and are the subject of a particular line of research around "place branding". We focused on the organisation 
brand category, in so far as it is directly affected by changes in management practices and that it crystallises the tensions resulting from a dissonance between traditional values (central core) and reality (modernisation of practices, managerialism).

Table 2: Composition of the sample of public brands studied

\begin{tabular}{|c|c|c|c|}
\hline $\begin{array}{ll}\text { Type } & \text { of } \\
\text { organisations } & \end{array}$ & $\begin{array}{l}\text { Name of the studied } \\
\text { structure (brand) }\end{array}$ & $\begin{array}{l}\text { Date of the } \\
\text { INPI } \\
\text { registratio } \\
\text { ns }\end{array}$ & Reference websites \\
\hline \multirow{2}{*}{ State } & $\begin{array}{l}\text { INSEE (Institut National } \\
\text { des Statistiques et } \\
\text { Etudes Economiques) }\end{array}$ & 2014 & http://www.insee.fr \\
\hline & Marine Nationale & 2014 & $\begin{array}{c}\text { http://www.defense.gouv.fr/marine, } \\
\text { http://www.colsbleus.fr/, } \\
\text { http://www.etremarin.fr/, }\end{array}$ \\
\hline National Agency & Atout France & 2009 & Htpp://www.atout-france.fr \\
\hline \multirow[t]{2}{*}{$\begin{array}{c}\text { Scientific and } \\
\text { Technological Public } \\
\text { Body }\end{array}$} & $\begin{array}{c}\text { CNRS (Centre National } \\
\text { de Recherche } \\
\text { Scientifique) }\end{array}$ & 2012 & http://www.cnrs.fr \\
\hline & INSERM & 1999 & http://www.inserm.fr \\
\hline \multirow{5}{*}{$\begin{array}{l}\text { Administrative Public } \\
\text { Body }\end{array}$} & Météofrance & 2009 & $\begin{array}{c}\text { http://www.meteofrance.com/ } \\
\text { http://www.meteofrance.fr/ } \\
\text { http://education.meteofrance.fr/ }\end{array}$ \\
\hline & $\begin{array}{c}\text { BnF (Bibliothèque } \\
\text { Nationale de France) }\end{array}$ & 2009 & http://www.bnf.fr \\
\hline & $\begin{array}{c}\text { Pôle emploi Agence } \\
\text { Nationale Pour l'Emploi }\end{array}$ & 2008 & http://www.pole-emploi.org \\
\hline & $\begin{array}{c}\text { IFCE (Institut Français } \\
\text { du Cheval et de } \\
\text { l'Equitation) }\end{array}$ & $\begin{array}{l}\text { Not } \\
\text { registered }^{6}\end{array}$ & http://www.ifce.fr \\
\hline & $\begin{array}{c}\text { Sécurité Sociale } \\
\text { l'Assurance Maladie }\end{array}$ & 2011 & $\begin{array}{c}\text { http://www.securite-sociale.fr/ } \\
\text { http://www.ameli.fr/ }\end{array}$ \\
\hline $\begin{array}{c}\text { Scientific, Cultural } \\
\text { and Professional } \\
\text { Public Body }\end{array}$ & $\begin{array}{l}\text { Université Paris- } \\
\text { Sorbonne }\end{array}$ & 2013 & http://www.paris-sorbonne.fr \\
\hline $\begin{array}{c}\text { Teaching and } \\
\text { Research Public } \\
\text { Body }\end{array}$ & $\begin{array}{c}\text { Polytechnique } \\
\text { L'X Ecole Polytechnique } \\
\text { Université Paris-Saclay }\end{array}$ & 2014 & https://www.polytechnique.edu \\
\hline \multirow[b]{2}{*}{$\begin{array}{c}\text { Industrial and } \\
\text { Commercial Public } \\
\text { Body }\end{array}$} & $\begin{array}{l}\text { CNES (Centre National } \\
\text { d'Etudes Spatiales) }\end{array}$ & 2013 & http://www.cnes.fr \\
\hline & $\begin{array}{c}\text { SNCF (Société } \\
\text { Nationale des Chemins } \\
\text { de Fer) }\end{array}$ & 2013 & http://www.sncf.com/fr \\
\hline
\end{tabular}

${ }^{6}$ IFCE has not been registered with the INPI proabably because this brand was registered in 2004 by a private company involved in training. 


\begin{tabular}{|c|c|c|c|}
\hline \multirow{4}{*}{$\begin{array}{c}\text { Healthcare Public } \\
\text { Body }\end{array}$} & Opéra National de Paris & 2012 & https://www.operadeparis.fr \\
\cline { 2 - 4 } & $\begin{array}{c}\text { Universcience } \\
\text { Roulpitaux de }\end{array}$ & 2011 & http://www.universcience.fr \\
\cline { 2 - 4 } & Hôpital Nord-Ouest & 2012 & http://www3.chu-rouen.fr/internet \\
\cline { 2 - 4 } & $\begin{array}{c}\text { Hôpital Necker enfants } \\
\text { malades }\end{array}$ & $\begin{array}{c}\text { Not } \\
\text { registered }\end{array}$ & http://hopital-necker.aphp.fr/ \\
\hline Public Body & Le Louvre & 2001 & http://www.louvre.fr/ \\
\hline
\end{tabular}

The information was collated from the "institutional" websites of these organisations and the available documents, such as business reports, presentation brochures, booklets, press releases, performance contracts, strategic plans, etc. They were recorded in twenty sheets and coded from a common grid (table 3). The idea is to work on the basis of the image the organisation conveys of itself and therefore of its brand.

Table 3: Analytical and coding grid of public brands

\begin{tabular}{|c|c|c|}
\hline & Purpose and interest & Features selected for analysis \\
\hline $\begin{array}{l}\text { Knowledge } \\
\text { function }\end{array}$ & $\begin{array}{l}\text { - Give information about the } \\
\text { organisation (what does } \\
\text { this PO do?) } \\
\text { - Understand the reality, } \\
\text { - Resituate the existence of } \\
\text { the PO in a context of } \\
\text { historical and social } \\
\text { change. }\end{array}$ & $\begin{array}{l}\text { - Is the background of the organisation explained? } \\
\text { Is it the subject of a consistent development? } \\
\text { - Is the environment in which it operates } \\
\text { (economic/competitive, social, regulatory) } \\
\text { specified? Are its evolutions highlighted? } \\
\text { - Are the activities, professions developed? Are new } \\
\text { activities (services) offered, highlighted? } \\
\text { - Has the PO remained unchanged (reference to } \\
\text { stability) or is it transformed? }\end{array}$ \\
\hline Identity function & $\begin{array}{l}\text { - Highlighting of a } \\
\text { specificity to be } \\
\text { safeguarded, } \\
\text { - Define if there is an } \\
\text { identity, }\end{array}$ & $\begin{array}{l}\text { - Has the brand been registered with the INPI? } \\
\text { - Reference to guardianship (prioritising the public } \\
\text { dimension) } \\
\text { - Presence of a logo, slogan or sentence reciting the } \\
\text { mission, } \\
\text { - Are the values visible? Are they the subject of an } \\
\text { explanatory development? } \\
\text { - What are the values (traditional, managerial) put } \\
\text { forward? }\end{array}$ \\
\hline $\begin{array}{l}\text { Orientation } \\
\text { function }\end{array}$ & $\begin{array}{l}\text { - Guide behaviour, } \\
\text { - Justify and explain } \\
\text { practices, }\end{array}$ & $\begin{array}{l}\text { What are the forms of orientation presented? } \\
\text { - External orientation: (citizens, users, customers, } \\
\text { partners ...) and/or internal (staff) } \\
\text { - "Social" orientation: public interest, } \\
\text { - "Customer/user orientation: user surveys, quality } \\
\text { of service charter, transparency, } \\
\text { - "Economic and financial performance" orientation: } \\
\text { cost control, profitability, productivity, } \\
\text { - "Organisational performance" orientation: } \\
\text { flexibility, speed, innovation, reorganisation, } \\
\text { rationalisation }\end{array}$ \\
\hline $\begin{array}{l}\text { Support } \\
\text { function }\end{array}$ & $\begin{array}{l}\text { - Justify a posteriori the } \\
\text { positions, the actions and } \\
\text { the behaviour }\end{array}$ & $\begin{array}{l}\text { - Does the organisation emphasise action elements } \\
\text { that trigger debates that are non-consensual? If yes, } \\
\text { does it provide arguments, demonstrations to }\end{array}$ \\
\hline
\end{tabular}




\section{The results and discussion}

The analysis reveals significant differences as regards the approach to the brand. While businesses use a widely disseminated structured approach that serves as a standard to create and display their brand, that of the POs is more fragmented.

Evidence does point to the existence of the public brand, but other evidence, on the other hand, leads us to qualify its scope due to what we would describe as its narrow use. A review of the results allows for four major findings:

$\Rightarrow$ A first finding, if we refer to the dates ${ }^{7}$ of the registration and protection applications (with the INPI) of the studied public brands, concerns the recency of awareness of the potential of the brand. All the brands were registered after 1997 with a very strong focus on the period after 2010 (table 2). This is due in large part to the advocacy work of the Agency of Intangible Heritage of the State.

$\Rightarrow$ The second finding highlights the importance of context as a trigger for the start of a brand policy or even, a real strategy for the most successful forms. The substrate on which the brand develops is clearly that of environmental changes: competition, budget constraints, technological changes, consolidations (mergers) of organisations are determining factors. The economic variable is repeatedly put forward; Sécurite Sociale Assurance Maladie advertises quite explicitly its reinforced responsibilities "better care for less" by replacing them in a process of historical and regulatory change, as if the new management practices, due to their unorthodoxy compared to traditional values, needed to be resituated. The CNRS anchors its brand in the partnership policy in the context of France's changing research landscape and the new powers granted by the law on freedoms and responsibilities now available to universities in the field of research, which reduce its historical field of intervention. The need to change is treated as an argument of "modernity", seeking to minimise the resistance to change that public opinion often associates with the PO. A brand sets out to be a reference and, logically

\footnotetext{
${ }^{7}$ We should point out that we find several registration dates for the same brand due to the classes of products or services covered. The Louvre brand for example was registered in 2011 on certain classes and in 2012 on others.
} 
enough, the PO structure their discourse around the skills, expertise, knowhow (IFCE, INSERM, Atout France, CNRS, CNES, INSEE, Météo France, Universcience, Polytechnique) and/or around the services provided (Hôpital Necker enfants malades, Le Louvre, SNCF) by clearly highlighting them through the explanation of the activities and professions. Competition is implicit, we can glimpse the desire to retain its "customers" or attract new ones, but only a few organisations, probably subject to stiffer competition, position their brand as an instrument at the service of attractiveness by asserting it (Université Paris-Sorbonne, Atout France, CNRS, Polytechnique). The changes witnessed by the environment are a reality to which the PO may seem ill-suited, however they take on board these new contextual features through the discourse by exposing them and make them a lever to introduce new practices and values, making it possible to reduce the dissonance between the central core and reality. Among these peripheral elements is the idea of doing more with less (BNF), of contributing to the public finance recovery effort (Opéra National de Paris) and of applying the principle of economic discipline (Marine Nationale). While the knowledge functions are marked, the support functions are unevenly presented and even absent for some PO (CNES, Hôpital Nord-Ouest, Université Panthéon Sorbonne, Atout France). The financial and economic environment, the expectations of users and, to a lesser degree, the technological and competitive developments are changing the framework of the action and lead to an adaptation of the practices or even organisational changes (Marine Nationale, Pôle emploi, SNCF, CHU Hôpitaux de Rouen).

$\Rightarrow$ The third finding concerns the low emphasis on traditional values associated with the brand despite being powerful principles rooted in the collective unconscious. Some organisations explicitly display them (IFCE, Marine National, CNRS Marine, Sécurité Sociale Assurance Maladie, CHU Hôpitaux de Rouen, Hôpital Nord-Ouest, Polytechnique), most simply mention them through their missions or objectives (Opéra National de Paris, INSEE, ParisSorbonne University, Universcience, Le Louvre, Pôle Emploi, BnF, INSERM), while others finally make no reference (Atout France, CNES, SNCF, Météo

\footnotetext{
${ }^{8}$ Customers is seen here in its broadest sense, in reference to the users, patients, citizens, the object of this article not being to discuss the specificities raised by these terms.
} 
France, Hôpital Necker). There is a wide variety of values, but overall the traditional ones are not present (equality, solidarity for Assurance Maladie Sécurité Sociale, equality, neutrality, continuity and adaptability for the $\mathrm{CHU}$ Hôpitaux de Rouen; accessibility for the Louvre, freedom for the CNRS). Values of a professional nature are the most cited, they refer to commitment, credibility (INSEE), autonomy (CNRS), expertise, efficiency, excellence (IFCE, Universcience), discipline (Marine nationale), transparency (INSEE), quality (Hôpital Necker), innovation (BnF, Hôpital Necker, Hôpital Nord-Ouest). Some human values are mentioned, such as sharing $(\mathrm{BnF})$, trust, honour (Marine nationale), humanity (Hôpital Nord-Ouest), integrity (Polytechnique). Professional values appear to be an interface between the increasingly competitive, economically binding environment with demanding stakeholders and traditional values that underpin large public service missions. By expressing their professional values (mostly imbued with the principles of NPM) the PO assert themselves as actors in tune with the realities and legitimise their role beyond their simple actions. Professional values manage to reconcile traditional values with managerial values. The missions and/or objectives of the organisations are systematically the subject of developments, and, for the holders of the brand, represent a concrete manifestation of their values. For some $\mathrm{PO}$, traditional values are strong markers "to combine past and future" (IFCE) and that "despite constant adaptation over time" (Le Louvre) thus highlighting a specificity: safeguard them (identity function).

$\Rightarrow$ The fourth finding makes it possible to determine the external orientation of the public brand. Most public brands are geared towards the general public (Marine Nationale, CNRS, INSEE, BnF, Le Louvre) or more specifically towards users (Health Insurance, SNCF, Polytechnique), individual customers (Opéra de Paris, Météo France), companies (CNES), elected officials and policy makers (CNES), institutions (IFCE) or professionals (doctors for Necker, teachers for Universcience) as well as the PO's partners (Atout France). The donors and sponsors are a clearly identifiable target of the public brand (Opéra National de Paris, Universcience, Le Louvre, Hôpital Necker). While the external orientation of the brand is established, it is rarely used as an internal management tool. Yet it is useful to strengthen the sense of belonging and give meaning to the actions of the officials. But in a context where 
managerialism is becoming widespread, where resistance to change is a fact, it is only very rarely mobilised in this dimension. Among the cases studied, only the Marine Nationale is developing an "employee" component of the brand by using a specifically internal brand; the "Cols bleus" brand. On the other hand, the expertise, the professional skills of human resources are frequently the subject of a communication component in itself. Similarly, one can identify a tentative appropriation of the public brand as an employer brand through a "we are recruiting" or "join us" section (Pôle Emploi, CHU Hôpitaux de Rouen, Hôpital Necker). Again, the Navy goes further by coming up with a real public employer branding through its "Etre marin" programme where the values are particularly emphasised.

Among the examples studied, the special case of groupings of organisations gives us valuable lessons about the nature of the public brand following a more studied rather than mechanical process and on its peculiarities. The creation of a new organisation seems to have an accelerating and structuring effect on the brand development process, as illustrated by the case of the IFCE and Universcience. Both entities were created in 2010 as part of a grouping of institutions. Since their inception, the new structures use the brand and apply it in a methodical way. The values, missions, objectives, context, positioning of the "offer" are developed in much the same way as within big companies. They (IFCE, Universcience, Opéra de Paris) draw on the image capital of the merged structures, retaining them as daughter brands. Their brands combine the demands imposed by new working methods and new practices more focused on streamlining and performance with the historical values.

The findings highlight a confused, rather illegible set of public brands in the "organisations" category. The market orientation is generally readily identifiable for most of the studied brands, through the focus on the user and the references to changes in the environment and the constraints it imposes. Innovation, modernisation, the measurement of the action, the very present efficiency, are elements that give concrete form to the evolution of the PO and their practices, consistent with the traditional values and the changes in the environment. The economic development of the brand is present not only through an offering of market services, but also through the "marketing" of expertise, as practised by the Louvre and the CNRS (training of companies). The values traditionally associated with the 
public sector are rarely mentioned, backing up the work of Brewer (2007), even though they are a prerequisite to the "brand orientation" advanced by Urde (1994) and Melin (1997). An organisation cannot create and develop a brand without having first identified the values that underpin it. The usefulness of a diagnosis of the values takes on its full meaning here. The public brand seems to be more of a communication tool than a management tool, and this even if the managerial dimension of the public brand is considered central and is peculiar to it (Gromark and Melin, 2013).

Public brands should be lively and embodied, that is to say, bearers of values that lead to the development of fully-fledged brands and not be mere names. Yet, by highlighting their objectives and missions, the PO tend to be more in the business of justifying their practices than of legitimising their actions. The quest for legitimacy is the reference point of the public brand, the element that drives it. It is up to the PO to identify the relevant legitimation support (Activity brand or Entity brand), the latter raising the issue of governance of the brand, and to determine the values (traditional, managerial or combined) that shape its identity to resituate the action.

\section{Conclusion}

This research is carried out within the framework of the PO's marketing practices, largely driven by the NPM current. It examines the phenomenon of public brands by studying more precisely the relationship they have with the values by using the principles of the central core theory. The analysis of what constitutes the public brand is conducted on the basis of the narrative dimension of the image that the public brand conveys. While it is indeed an institutional brand owned by a public entity designed to give life to the organisation within the social body by strengthening its legitimacy and animating the public space, the twenty cases studied make it possible to identify a rather loose and heterogeneous conception and use. This is probably explained by the fact that the PO are at various stages in their learning curve and in the process of brand management. While some are associated with the expression of public brand, they do not yet represent one in their own right.

The proposed typology of public brands needs to be fine-tuned but it offers a first interpretative framework of the phenomenon. The research does not make it possible to substantiate the studies on brand orientation in all their dimensions. The 
philosophical foundations that emerge through the mission, vision and core values, are not expressed or are sometimes expressed in very tenuous way, just as, while the external approach is clear, the internal approach, in most cases, is lacking. This study could be supplemented by interviewing those responsible for the management of these brands to gain a greater understanding of the intention associated with its use.

\section{Bibliography}

AAKER, D. et JOACHIMSTHALER, E. (2000) "The brand relationship spectrum", California Management Review, 42(4): 8-23.

ABRIC, J. C. (1979) Représentations sociales et interaction conflictuelle: Etudes expérimentales. In : Conference on Social Representations, Laboratoire européen de psychologie sociale, Paris.

ABRIC, J-C. (1994) «Les représentations sociales : aspects théoriques », Pratiques sociales, représentations, Puf, Paris: 11-35.

ABRIC, J.-C. (2001) "L'approche structurale des représentations sociales : développements récents», Psychologie \& Société, 4, (2): 81-104

ANTONSEN, M. et JORGENSEN, T.B. (1997) «The "Publicness » of Public Organizations», Public Administration", 75: 337-357

ASHFORTH, B. E. et MAEL, F.A. (1989) "Social identity theory and the organization», Academy of management review, 14(1): 20-39

ASHFORTH, B. E. et MAEL, F.A. (1996) «Organizational identity and strategy as a context for the individual», Advances in strategic management, 13: 19-64

BUFFAT, A. (2014) « «C'est l'étiquette État, mais comme une PME ! : Hybridation organisationnelle, sentiments d'appartenance et stratégies identitaires des collaborateurs d'une caisse publique de chômage en Suisse", Revue Internationale des Sciences Administratives, 80(1): 71-89

BOZEMAN, B. (2007) «La publicitude normative: comment concilier valeurs publiques et valeurs de marché », Politiques et Management Public, 25 (4): 179-211

BRERETON, M. et TEMPLE, M. (1999) "The new public service ethos: an ethical environment for governance", Public Administration, 77(3): 455-474.

BREWER, B. (2007) "Citizen or customer? Complaints handling in the public sector", International Review of Administrative Sciences, 73: 549-556. 
BRUNSSON, N. et SAHLIN-ANDERSSON, K. (2000) "Constructing organizations: The example of public sector reform", Organization studies, 21: 721-746.

CEGARRA, J. et MICHEL, G. (2001) "Co-branding: clarification du concept ", Recherche et applications en marketing, 16(4): 57-69.

DAHLQVIST, U. et MELIN, F. (2010) Brands in public service, Varumärken i offentlig tjänst, Malmô: Liber.

DELAGADO-BALLESTER, E. et MUNUERA-ALEMAN, J.L. (2005) "Does brand trust matter to brand equity?", Journal of Product \& Brand Management, 14 (3): 187-196

DENHARDT, R. B. et DENHARD, J. V. (2000) "New public Service", Public Administration Review, 60(6): 549-559.

DENHARDT, J. V. et CAMPBELL, K. B. (2006) The role of democratic values in transformational leadership, Administration and Society 38: 556-572

EMERY, Y. et MARTIN, N. (2010) «Le service public au XXlème siècle : identités et motivations dans l'après-fonctionnariat", Paris, L'Harmattan.

FACAL, J. et MAZOUZ, B. (2013) «L'imputabilité des dirigeants publics, éléments de théorie et observations tirées de l'expérience québécoise ", Revue française de Gestion, 237(8): 117-132.

FORTIER, I. (2010a) «La modernisation de l'état québécois: la gouvernance démocratique à l'épreuve des enjeux du managérialisme ", Nouvelles pratiques sociales, 22(2): 35-50.

FORTIER, I. (2010b) «Expérience des réformes et transformation de l'ethos de service public dans l'administration publique québécoise. " Pyramides, Revue du Centre d'études et de recherches en administration publique, 19: 71-86.

FORTIER, I. (2013) «Ethos public et quête de sens dans cette ère de réforme : le NPM, ses critiques et les luttes pour la reconnaissance d'une spécificité du secteur public », @GRH, 9: 157-189.

FREDERICKSON, H. G. et HART, D. K. (1985) «The public service and the patriotism of benevolence», Public Administration Review, 547-553.

FREDERICKSON, H. G. (1994) «Can public officials correctly be said to have obligations to future generations? ", Public Administration Review, 457-464

FREDERICKSON, H. G. (2002) "Confucius and the moral basis of bureaucracy», Administration \& Society, 33(6): 610-628 
GRAHAM, P. (1994) "Marketing in the public sector inappropriate or merely difficult?", journal of Marketing Management, 10: 361-375.

GROMARK, J. et MELIN, F. (2013) "From market orientation to brand orientation in the public sector", Journal of Marketing Management, 29(9/10): 1099-1123.

GUZMAN, F et SIERRA, N. (2012) «Public-private collaborations: branded public services?, European Journal of Marketing»,46(7/8): 994-1012.

HONDEGHEM, A. et VANDENABEELE, W. (2005) Valeurs et motivations dans le service public, Revue française d'administration publique, (3): 463-479.

HOOD, C. (1991) "A public management for all seasons?", Public Administration, 69: 3-19.

HOOD, C. (1995) Contemporary public management: a new global paradigm?, Public policy and administration, 10(2): 104-117.

JOANNIDES, V. et JAUMIER, S. (2013) « De la démocratie en Amérique du Nord à l'accountability à la française Comprendre les origines sociopolitiques de l'accountability », Revue française de gestion, 237(8): 99-116.

KAPFERER, J.N. (1991) La marque capital de l'entreprise, créer et développer des marques fortes, Les éditions d'Organisation, Paris.

KAPFERER, J.N. (1999) La marque capital de l'entreprise, Les éditions d'Organisation, Paris.

KERNAGHAN, K. (2000) "The post-bureaucratic organization and public service values", International Review of administrative sciences, 66: 91-104.

KERNAGHAN, K. (2003) "Integrating values into public service: the values statement as centerpiece", Public Administration Review, 63(6): 711-719.

KIROVSKA, Z. et SIMONOVSKA, K. (2013) "Branding and its sustainability in the public sector", Journal of sustainable development, 4(7): 55-70.

LÉVY, M. et JOUYET, J. P. (2006) L'économie de l'immatériel: la croissance de demain., La Documentation française.

LEWI, G. et LACOEUILHE, J. (2007) Branding management: la marque, de l'idée à I'action. Pearson Education France.

MAZOUZ, B., GRAZON, C. et PICARD, P. (2012) "Les déviances dans les organisations publiques en quête de performance. Vers une gestion prophylactique des risques de déviance ", Management International, 16(3): 91-100. 
MELIN, F. (1997) "Varumärket som strategiskt konkurrensmedel. Om konsten att bygga upp starka varumärken (the brand as a strategic competitive tool. The art of building strong brands)", Lund: Lund University Press (Malmö: Team offset and media).

MICHEL, G. (1999) «L'évolution des marques: approche par la théorie du noyau central. ", Recherche et Applications en Marketing, 14(4): 32-53.

MOLINER, P. (2001) La dynamique des représentations sociales, Grenoble: PUG.

MULLER, P. (2006) "Le client-centrisme : une nouvelle forme de relation entre l'État et les citoyens", Politiques et Management Public, 24(3): 1-4.

OLSEN, J.P. (2008) "Institutional autonomy and democratic government", Working Paper $n^{\circ} 20$, ARENA.

PERRY, J. et RAINEY, H. (1988) «The Public-Private Distinction in Organization Theory: A Critique and Research Strategy», Academy of Management Review. 13(2): 182-201

PERRY, J.L. et WISE R. (1990) "The motivational bases of public service", Public Administration Review, 50: 367-373.

PIERRE, J. (2009) "New Governance, New Democraty?", The QoG Institute for Quality of Government, Working paper series, 4.

POLLITT, C. (2007) "The new public management: an overview of its current status" revista administratie si management public, 8: 110-115.

POLLITT, C. et BOUCKAERT, G. (2004) Public management reform. A comparative analysis, Oxford, Oxford University Press.

RAINEY, H. G. (1989) «Public Management: Recent Research on the Political Context et Managerial Roles, Structures, et Behaviors», Journal of Management, 15(2): 229-250

RAMSEY, W. et DEPAUL, M. (1999) «Rethinking intuition», The Psychology of Intuition and Its Role,

RAVASI, D. et SCHULTZ, M. (2006) «Responding to organizational identity threats: Exploring the role of organizational culture», Academy of management journal, 49(3): 433-458

RONDEAU, G. (2007) "L'identité des agents face aux réformes publiques, perte de repères ou nouvelles racines ? ", Dilemmes de la GRH publique. EMERY Y. et GIAUQUE D coord., Lausanne, 65-87. 
SAYRE, W. S. (1958) «Premises of public administration: Past and emerging», Public Administration Review, 102-105.

SILICANI, J.L. (2007) Livre blanc sur l'avenir de la fonction publique, la documentation française.

SCHEDLER, K. et PROELLER, I. Eds (2007) Cultural aspects of public management reform. Oxford, UK, Elsevier.

SULEIMAN, E. (2003) Dismantling Democratic State, Princeton, N.J., Princeton University Press.

URDE, M. (1994) "Brand orientation, a strategy for survival", Journal of consumer marketing, 11(3): 18-32.

URDE, M. (1997) "Märkesorientering: utveckling av varumärken som strategiska resurser och skydd mot varumärkesdegeneration (Brand orientation; development of brands as strategic resources and protection against trademark degeneration)", Lund: Lund University Press

URDE, M. (1999) "Brand orientation: a mindset for building brands into strategic resources", Journal of marketing management, 15: 117-133.

URDE, M. (2003) "Core value-based corporate brand building", European Journal of marketing, 37: 1037-1040.

VERNETTE, E. (2008) "Les atouts et les pièges de la personnalité de marque ", Décisions Marketing, 1: 9-31.

WALSH, K. (1994) "Marketing and public sector management", European journal of Marketing, 28/3: 63-71. 
Levels of analysis of public governance

(Facal and Mazouz, 2013)

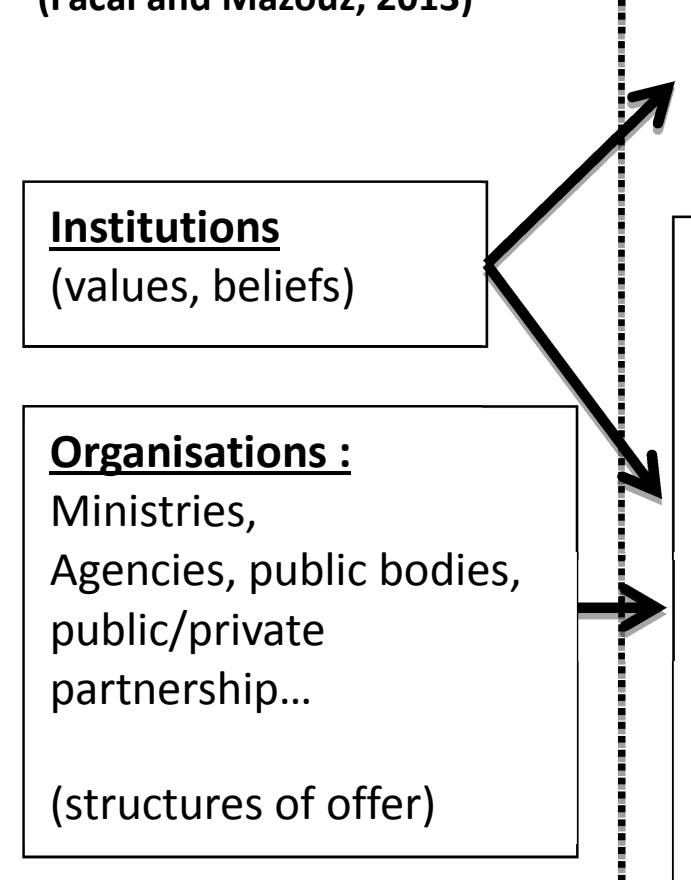

Architecture of the public brand

\section{State Brand (Master Brand)}

Example: France

\section{Organisation Brands}

"Activity" brands (Umbrella)

(warranty brands referring to a field of action)

Examples: CHU, Musée de France, AP-HP SECURITE SOCIALE L'Assurance Maladie,

"Entity" brands (institutional)

(reference to the competence)

Examples: Necker, Le Louvre, La Sorbonne, Louis le Grand

\section{Management} framework Projects,

\section{Management} tools

Action brand (reference to a programm, an event, a project)

Example: Défi Jeune, Programme National Nutrition

Santé, Grand Paris 